\title{
Reforma Izbornog zakonodavstva Kako do integriteta i kredibiliteta izbornog procesa?
}

\author{
Vehid Šehić \\ Forum građana Tuzle \\ vehid_sehic@yahoo.com
}

Izbori u Bosni i Hercegovini, nakon potpisivanja Općeg okvirnog sporazuma za mir u Bosni i Hercegovini, su se do 2000. godine održavali na osnovu Privremenih pravila u organizaciji OSCE-a, a nakon 2001. godine kada je u Parlamentarnoj skupštini BiH donesen Izborni zakon BiH, formirana je Izborna komisija $\mathrm{BiH}$ koja se sastojala od sedam članova, od kojih su četiri bili iz reda državljana $\mathrm{BiH}$ i to iz reda Bošnjaka, Hrvata, Srba i ostalih i tri međunarodna koja su činila šef misije OSCE-a u BiH kao i njegov zamjenik i zamjenik Visokog predstavnika u BiH. Time su se stekli i uslovi da Izborna komisija preuzme obavezu i odgovornost za provođenje izbora $\mathrm{u}$ skladu sa Izbornim zakonom, a počev od 2002. godine do sada, organizovala je 10 izbornih ciklusa. Analizom odredaba Izbornog zakona lako je uočiti da su određene odredbe Izbornog zakona diskriminatorske, ali su usklađene sa postojećim ustavnim rješenjem.

Kako Ustav BiH nije obezbijedio jednakopravnost svih građana, a samim tim i naroda u BiH kada je u pitanju aktivno i pasivno biračko pravo, a kako je Izborni zakon morao da bude u skladu sa Ustavom BiH, taj vid diskriminacije je ugrađen i u sam Zakon, tako da se građani Bošnjačke i Hrvatske nacionalnosti u RS nisu mogli kandidovati za člana Predsjedništva $\mathrm{BiH}$, kao ni građani Srpske nacionalnosti iz Federacije BiH.

Od 2002. godine BiH je postala punopravan član Vijeća Evrope, čime smo i dio sudskog suvereniteta prenijeli na Evropski sud za ljudska prava u Strazburu.

Iako je BiH ratificirala Evropsku konvenciju o ljudskim pravima i osnovnim slobodama kao i Pakt o građanskim i političkim pravima, do danas nije uskladila Ustav $\mathrm{BiH}$ sa ovim međunarodnim ugovorima.

Pakt o građanskim i političkim pravima propisuje univerzalno i jednakopravno pravo glasa kao i zabranu diskriminacije. Ako ovom dodamo da 
je $\mathrm{BiH}$ ratifikovala i Protokol 12 Evropske konvencije o ljudskim pravima i osnovnim slobodama, jasno je da je zabranjen svaki vid diskriminacije. Zbog političke neodgovornosti dosadašnjih nosilaca zakonodavne vlasti, Ustav $\mathrm{BiH}$ nije usklađen sa ovim međunarodnim ugovorima. Kako su se članstvom u Vijeću Evrope stekli uslovi da građani BiH mogu pokretati postupke zbog kršenja ljudskih prava, Evropski sud za ljudska prava u Strazburu donio je 5 odluka i to u slučajevima: Sejdić - Finci, Pilav, Zornić, Šlaku i Pudarić protiv $\mathrm{BiH}$, a kojima je omogućeno aktivno i pasivno biračko pravo pripadnicima nacionalnih manjina, građanima Srpske, Hrvatske i Bošnjačke nacionalnosti da mogu biti birani u državne institucije ove države (predsjedništvo) bez obzira na mjesto prebivališta. Posebno je značajna odluka Zornić kojom se garantuje svakom građaninu BiH aktivno i pasivno biračko pravo, jer se implementacijom ove odluke implementiraju i ostale četiri odluke Evropskog suda za ljudska prava iz Strazbura, čime se štiti aktivno i pasivno biračko pravo ne samo Bošnjacima, Hrvatima, Srbima i nacionalnim manjinama nego i građanima koji se etnički ne izjašnjavaju.

Ilustracije radi, samo je u slučaju Sejdić - Finci bila formirana parlamentarna komisija 2012. godine od predstavnika tadašnjih parlamentarnih stranka, ali bez konačnog prijedloga.

Implementacijom ovih odluka u Ustav BiH, steći će se uslovi za izmjene Izbornog zakona $\mathrm{BiH}$ i time ukinuti diskriminacija u izbornom procesu.

Posebno zabrinjava pojava promjene etničke pripadnosti u izbornim procesima iz političkih razloga i na takav način se zloupotrebljava jedno od temeljnih ljudskih prava da svaki građanin može promijeniti svoju etničku pripadnost. To se posebno odnosi na slučajeve popune Doma naroda $\mathrm{u}$ Parlamentu Federacije BiH i Vijeću naroda u RS-u, ali i kod imenovanja u izvršnu vlast. Nažalost, ovo se vrlo često primjenjuje i za imenovanja i u druge institucije države $\mathrm{BiH}$. Zato bi u Ustavu $\mathrm{BiH}$ trebalo predvidjeti zabranu promjene etničkog identiteta u tri uzastopna izborna ciklusa.

Osim odluke Evropskog suda za ljudska prava, još uvijek nisu implementirane ni sve odluke Ustavnog suda BiH od kojih treba posebno izdvojiti odluku o ravnopravnosti tri naroda na cijeloj teritoriji $\mathrm{BiH}$ (u tri kantona još uvijek građani srpske nacionalnosti nisu ravnopravni sa ostala dva naroda) i odluke u slučaju Ljubić, a tiču se promjene Izbornog zakona BiH. U skladu sa ovim, potrebno je izmjenama Izbornog zakona obezbijediti minimalnu zastupljenost sva tri naroda u svim predstavničkim tijelima na svim nivoima, što sada nije slučaj, a čime bi se obezbijedilo da Dom naroda Parlamenta Federacije $\mathrm{BiH}$ radi u sastavu kako je to predviđeno Ustavom (klub Srba). 
Prema Izbornom zakonu $\mathrm{BiH}$, Centralna Izborna komisija je odgovorna za organizaciju i provođenje izbora u skladu sa zakonom i podzakonskim aktima. Osim Centralne Izborne komisije, veliki dio odgovornosti snose i Gradske i Općinske Izborne komisije kao i birački odbori. Dosadašnja iskustva ili naučene lekcije iz deset izbornih ciklusa, pokazuju da su najslabiji dio izborne administracije birački odbori, koji su jedini u direktnom kontaktu sa biračima. Dio neodgovornih članova biračkih odbora, kršeći odredbe Izbornog zakona kao i provedbenih akata koje donosi Centralna izborna komisija te falsifikujući izbornu volju građana birača, dovode u pitanje integritet i kredibilitet izbornog procesa kao i samih rezultata izbora, što kod građana stvara nepovjerenje u izborni proces i dobrim dijelom utiče na samu izlaznost na izbore. Do sada je CIK BiH izrekla na hiljade novčanih kazni, ali to nije proizvelo željene rezultate jer je izostala i krivična odgovornost neodgovornih članova biračkih odbora iz kojeg razloga bi trebalo drastično povećati novčane kazne koje se izriču. Ovo ističem iz razloga što bi kroz izmjene Izbornog zakona trebalo utvrditi odgovornost i sankcije za one političke subjekte za koje se dokaže da su instruisale svoje članove biračkih odbora da favorizuju tu stranku, jer ćemo i dalje iz izbora u izbore imati kontaminiran izborni proces.

Ovo je potrebno učiniti radi vraćanja povjerenja u izborni proces i konačne rezultate jer, nažalost, ne možemo reći da su dosadašnji izbori bili pošteni i slobodni i sa rezultatima koji istinski predstavljaju slobodno izraženu volju građana birača.

Svjedoci smo još jedne anomalije u političkom životu BiH. Nakon uvođenja višepartijskog sistema, bilo je normalno da u početku imamo veliki broj političkih stranaka što je karakteristika svih zemlja koje su iz jednopartijskog sistema ušle u politički pluralizam. Logika nalaže da se iz izbornog u izborni ciklus, broj političkih stranaka smanjuje te da se jasno profilišu ideološke političke stranke ljevice, desnice i centra, što se desilo u skoro svim tranzicionim društvima osim u BiH. Razlog tome je što se politika shvatila kao sredstvo ostvarivanja ličnog, a ne općeg interesa. Kada moral nestane u politici, otvoren je put ka neuspješnim politikama, što karakterizira politički život u $\mathrm{BiH}$, ali i put ka nepotizmu, korupciji, zarobljavanju institucija države, stvarajući društvo privilegovanih i potlačenih te se na takav način ruše ustavni principi jednakopravnosti, pravne sigurnosti i jednakih šansi za sve građane. Ovo se može vidjeti i u Izbornim procesima u BiH.

Izbornim zakonom, kao i provedbenim aktima, propisano je da svi politički subjekti (političke stranke, koalicije, nezavisne liste i nezavisni kandidati) 
koji su ovjereni da učestvuju na izborima, kada podijele mjesta u biračkim odborima, imaju ravnopravan status u izbornim jedinicama u kojima su ovjerene. Jasno je Zakonom predviđeno da u biračkom odboru politički subjekat može imati samo jednog člana (po Izbornom zakonu, postoje birački odbori sa tri i pet članova). Ovo je logično rješenje jer se smatralo da će i unutar biračkog odbora postojati samokontrola koja je trebala obezbijediti zakonitost provođenja izbora. Međutim, ovo se počelo zloupotrebljavati od strane dijela političkih stranaka tako što su se počeli prijavljivati nezavisni kandidati za koje su plaćali zakonom utvrđenu taksu i time im omogućili da nakon ovjere učestvuju u raspodjeli biračkih mjesta koje su oni ustupali nekoj stranci (a nakon utvrđenih rezultata izbora utvrđeno je da veliki broj nezavisnih kandidata i malih stranaka nije dobio ni jedan glas). Veliki broj lokalnih političkih stranaka, ali i etabliranih, pojavljuju se na izborima u izbornim jedinicama širom $\mathrm{BiH}$ gdje uopšte nemaju svoj organizacioni dio. Ovakva situacija omogućava da dođe do razmjene mjesta u biračkim odborima, a neke od manjih političkih stranaka i prodaju biračka mjesta, te se na ovaj način krši Izborni zakon, jer se vrlo često dešava da imamo jednostranačke biračke odbore.

Ovakva masovna pojava dovodi u pitanje kredibilitet izbornog procesa. Ovo je razlog da se mora donijeti Zakon o političkim organizacijama na državnom nivou, ali i dopuniti Izborni zakon $\mathrm{BiH}$, na način da je za ovjeru određene političke stranke preduslov da se može ovjeriti za učešće na izborima ukoliko ima aktivan opštinski odbor najmanje šest mjeseci prije održavanja izbora. Također se moraju predvidjeti i sankcije za one nezavisne kandidate i političke stranke koji su učestvovali na izborima, ne da bi dobili naklonost birača nego da bi ustupili svoje mjesto u biračkom odboru nekom političkom subjektu ili prodali svoja biračka mjesta, zabranom učešća na sljedećim izborima.

Samo striktnim provođenjem zakona mogu se uočiti određene nepreciznosti u Izbornom zakonu $\mathrm{BiH}$ te je kroz dopune ili izmjene potrebno jasno precizirati pravnu normu, da bi se izbjegla različita ekspanzivna tumačenja.

U poglavlju 14. Izbornog zakona $\mathrm{BiH}$, predviđeni su instituti ponovljenih, odgođenih i prijevremenih izbora i jasno je precizirano kada se oni primjenjuju. Na posljednjim lokalnim izborima koji su održani 15. 11.2020. godine, kandidat za gradonačelnika Travnika, preminuo je na dan izbora, a koji je dobio najveći broj glasova, pa iz tog razloga njegov mandat nije potvrđen odlukom Centalne izborne komisije.

U ovakvim situacijama se ne može primijeniti institut ponovljenih ili odgođenih izbora. Za donošenje odluke o održavanju prijevremenih izbora, 
potrebno je da je neki organ raspušten ili da je mandat prestao u skladu sa Ustavom ili Izbornim zakonom. Zato je potrebno jasno precizirati i ovakve situacije u Izbornom zakonu $\mathrm{BiH}$.

Analizom posljednjih lokalnih izbora, ukazala se potreba da se mora dopuniti Izborni zakon u slučajevima kada kandidati za načelnika/gradonačelnika imaju isti broj glasova što se može desiti jer je na ovim izborima, razlika u glasovima kandidata bila minimalna ( 2 do 5 glasova).

Nejasne su odredbe Izbornog zakona u slučajevima kada u toku izbornog dana dođe do prekida glasanja usljed više sile (poplave, zemljotres itd.) ili narušavanja javnog reda i mira iz kojeg razloga treba predvidjeti i ovakve situacije. Ako bi se primjenjivao institut odgođenih izbora, potrebno je jasno precizirati da li bi se, u slučaju da je u narušavanju javnog reda i mira učestvovao i neko sa kandidatskih listi (općinsko vijeće, načelnika/gradonačelnika) iz kojih su razloga i sankcionisani skidanjem sa ovjerene kandidatske liste, dozvolilo političkim subjektima da u natjecanju za načelnika/gradonačelnika mogu predložiti drugog kandidata ili ne (slučaj Stolac).

U cilju jednakopravnosti svih građana $u \mathrm{BiH}$, potrebno svim građanima sa aktivnim biračkim pravom omogućiti da biraju gradonačelnika, što nažalost nije slučaj (Mostar, Grad Sarajevo).

Određene izmjene Izbornog Zakona BiH, umanjile su moć glasa birača. Naime, unutarstranački prag na kandidatskim listama političkih subjekata koji je bio $5 \%$, povećan je na $10 \%$ kada su u pitanju lokalni izbori, a $20 \%$ na općim izborima. Inače, Evropski standard u državama koje imaju poluotvorene liste sa preferencijalnim načinom glasanja je između 5 i $10 \%$. Zato je potrebno uvesti jedinstven prag od $10 \%$ i na općim izborima i time omogućiti da se poštuje volja birača političkog subjekta, a ne onih koju kreiraju redoslijed na listama.

Izborni rezultati moraju odražavati istinsku slobodnu volju građana birača što nažalost kod nas nije slučaj jer se u predizbornoj kampanji koja počinje 30 dana prije dana održavanja izbora, a kako je utvrđeno Izbornim zakonom, od strane određenih političkih subjekata ne biraju sredstva da se dobije naklonost birača (kupovina, nerealna obećanja, prijetnja, kreiranje etničke netrpeljivosti) što kontaminira čitav izborni proces. Također, u budućim izmjenama Izbornog zakona posebno treba predvidjeti sankcije za one političke subjekte koji odmah nakon donošenja odluke o raspisivanju izbora, a prije zakonom predviđenog roka za izbornu kampanju, počinju voditi (preuranjenu) izbornu kampanju, što nije u skladu sa Izbornim zakonom pa je kao takvu možemo nazvati nezakonitom. Mnogi akteri političkog i izbornog procesa 
zloupotrebljavaju činjenicu da $\mathrm{u}$ ovom periodu nisu predviđene sankcije $\mathrm{u}$ Izbornom zakonu, tako da treba razmisliti na koji način spriječiti takvo ponašanje koje se ponavlja iz izbornog ciklusa u izborni ciklus.

Potrebno je u izborni proces uvesti nove tehnologije koje se primjenjuju u nekim državama Evrope, tako da treba razmišljati o uvođenju biometrijske elektronske identifikacije birača, skenera ili sličnih tehnologija koje bi sigurno na minimum svele mogućnost falsifikovanja izbornih rezultata od strane neodgovornih članova biračkih odbora.

Na kraju moram istaći i činjenicu da mi u skladu sa evropskim izbornim standardima imamo odvojen izborni proces kada su u pitanju lokalni i opći izbori. To ne bi bio dio problema da prema Izbornom zakonu nemamo daleko najduži izborni period u Evropi, a koji traje 150 dana od dana donošenja odluke o raspisivanju izbora do dana održavanja i još 30 dana do potvrđivanja izbornih rezultata od strane CIK-a BiH. U Evropi, ali i u našem okruženju, taj period je od 30 do 60 dana od dana donošenja odluke. Zato je i u našem izbornom zakonodavstvu potrebno skratiti izborni period na 90 dana čime ne bismo, kao društvo, stalno bili u izbornom procesu i izbornoj kampanji koji nažalost u pravilu stvaraju etničke tenzije, a manje se bave životnim pitanjima građana u $\mathrm{BiH}$, bez obzira da li se radi o općim ili lokalnim izborima. 